András Handl*

\title{
From Slave to Bishop. Callixtus' Early Ecclesial Career and Mechanisms of Clerical Promotion
}

https://doi.org/10.1515/zac-2021-0013

\begin{abstract}
Bishop Callixtus I of Rome (217?-222?) is well known for his position

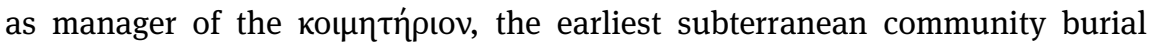
ground, today known as the Catacombs of Callixtus. Less well documented, but particularly formative is, however, Callixtus' early ecclesial career starting with his recognition as an authentic confessor shortly after his return from the mines of Sardinia. This contribution aims to shed some light on this formative period and explores the mechanisms behind Callixtus' promotion to paid ecclesial ministry. It argues that Callixtus' association with the clergy was neither an honorary, that is, automatic admission, nor merely a pious act to honour his individual and spiritual achievement. It seems, it was also a powerful instrument to financially support, integrate, and if necessary, control independent spiritual authorities. Moreover, Callixtus' installation in active ministry, as well as that of other confessors, show typical patterns of client-patron relationship.
\end{abstract}

Keywords: Callixtus I of Rome, Cyprian of Carthage, Natalius, confessor, clerical career, patronage, paid clergy, Traditio apostolica, Refutatio omnium haeresium

Although Callixtus was bishop of Rome between ca. 217 and ca. 222, he is-ironically-far better known for those activities he pursued before he ascended the episcopal throne. Oddly enough, he gained a reputation by the management of

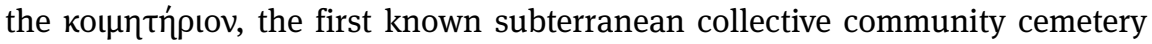
for Christians at Rome. Entombed elsewhere, his name was nonetheless firmly linked from early times on to the complex which served as a burial ground for generations of Roman bishops. ${ }^{1}$ This very down-to-earth responsibility at the

1 For the Catacomb of Callixtus see Emanuela Prinzivalli, "Callisto I, Santo," in Enciclopedia dei Papi (ed. Sara Esposito and Giulia Barone; Roma: Istituto della Enciclopedia Italiana, 2000),

*Corresponding Author: András Handl, History of Church and Theology Research Unit, Faculty of Theology and Religious Studies, KU Leuven, Sint-Michielsstraat 4 box 3101, BE-3000, Leuven, Belgium; e-mail: andras@handl.hu

2 Open Access. (C) 2021 András Handl, published by De Gruyter. (c) BY This work is licensed under the Creative Commons Attribution 4.0 International License. 
side of bishop Zephyrinus (199?-217?) has fuelled speculation about Callixtus' ecclesial career and particularly about the precise nature of his ministry. ${ }^{2}$ A not particularly recent, yet still representative verdict of Bernhard Domagalski puts the current communis opinio in a nutshell: "der Diakonat des Callixtus [wird] von niemandem mehr bestritten." 3 While previous scholarship was predominantly engaged with the Amtsfrage, the early ecclesiastical career of Callixtus was often ignored or illuminated only from narrow perspectives. ${ }^{4}$ This contribution aims to re-examine this rather obscure yet formative period of his life and outline the processes and mechanisms at play, which eventually made a slave into the bishop of Rome.

\section{Callixtus, the Confessor}

The little we know about Callixtus and his life is preserved in a heresiology, the Refutatio omnium haeresium (henceforth Refutatio). This writing is traditionally attributed to Hippolytos Romanos ( +235$)$, who was supposed to be not only an author of dozens of literary works, but also the arch-enemy of Callixtus, the first anti-pope in history, and eventually a martyr, who was reconciled with the church before his death by the co-martyr, bishop Pontianus of Rome (230-235). ${ }^{5}$ Recent scholarship, however, has expressed severe doubts about this traditional identification and has tended to see the author as an anonymous Christian intel-

237-346; Lucrezia Spera, “Cal(1)isti Coemeterium (via Appia)," in Lexicon topographicum urbis Romae. Suburbium 2 (ed. Vincenzo Fiocchi Nicolai and Adriano La Regina; Roma: Ed. Quasar, 2004), 32-44.

2 Cf. Ignaz von Döllinger, Hippolytus und Kallistus: oder die Römische Kirche in der Ersten Hälfte des Dritten Jahrhunderts; mit Rücksicht auf die Schriften und Abhandlungen der HH. Bunsen, Wordsworth, Baur und Gieseler (Regensburg: Manz, 1853), 123-124. Von Döllinger's monograph was published hardly two years after the editio princeps of the Refutatio by Emmanuel Miller: Origenis Philosophumena sive omnium hæresium refutatio (Oxonia: Oxonii Typographeum Academicum, 1851).

3 Bernhard Domagalski, “Der Diakonat als Vorstufe zum Episkopat,” Studia Patristica 29 (1997): (17-24) 19: "Nowadays, Callixtus' diaconate is challenged by no one."

4 E. g. Henneke Gülzow, "Kallist von Rom: Ein Beitrag zur Soziologie der römischen Gemeinde,” ZNW 58 (1967): (102-121) 113; Georg Schöllgen, Die Anfänge der Professionalisierung des Klerus und das Kirchliche Amt in der Syrischen Didaskalie (JbAC.E 26; Münster: Aschendorff, 1998), 53-55.

5 An excellent overview of the traditional view offers Clemens Scholten, "Hippolytos II (von Rom)," RAC 15 (Stuttgart: Hiersemann, 1991): 492-551. 
lectual leading a small independent house community in Rome. ${ }^{6}$ For the sake of convenience and to avoid confusion, he will be referred to as "Author" or "Author of the Refutatio."

The Refutatio offers an elaborate, yet vitriolic curriculum vitae of Callixtus. The account's primary purpose is to deliver incontrovertible proof that the bishop was mainly a magician and a conman but certainly not an authentic martyr or confessor. ${ }^{7}$ The story begins to be interesting for the current issue when Callixtus was sentenced and deported to the mines of Sardinia by the praefectus urbi Fuscianus, probably around $187 .{ }^{8}$ He was freed during a rescue mission launched by Marcia, the concubine of the emperor Commodus, who was acting since the execution of Bruttia Crispina as a de facto empress. Callixtus returned to Rome probably around $190 .{ }^{9}$ Unfortunately, at this point the account becomes rather superficial and merely touches upon the subsequent events. Yet, one learns a quite important detail. After his return, some disturbances arose within the Christian community, which forced bishop Victor (189?-199?) to "sen[d] him to remain in Antium, assigning him a monthly allowance." 10 The Refutatio remains silent about the more than ten years Callixtus spent in the idyllic holiday resort of Antium in the shadow of magnificent seaside villas of emperors and the Roman aristocracy. Bishop Zephyrinus (ca. 199?-ca. 217), Victor's successor, urged him to return to Rome. Callixtus' return marks the beginning of a very close working relationship between the bishop and the ex-slave confessor. He was appointed

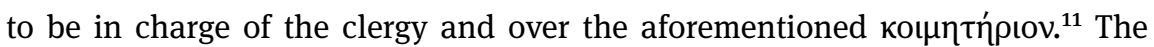

6 Manlio Simonetti, "Per un Profilo dell'Autore dell'Elenchos," Vetera Christianorum 46 (2009): 157-173; Clemens Scholten, "Autor, Anliegen und Publikum der Refutatio," in Des Évêques, des Écoles et des Hérétiques: Actes du Colloque International sur la "Réfutation de Toutes les Hérésies", Genève, 13-14 Juin 2008 (ed. Gabriella Aragione and Enrico Norelli; Lausanne: Éditions du Zèbre, 2011), 135-166; Emanuele Castelli, “L'Elenchos, Ovvero una 'Biblioteca' contro le Eresie," in 'Ippolito' Confutazione di tutte le Eresie (ed. Aldo Magris; Letteratura Cristiana Antica. Nuova Serie 25; Brescia: Morcelliana, 2012), 21-56; András Handl, Callixtus I, der Bischof von Rom und der Konflikt um seine Person in der Refutatio omnium haeresium (VCS; Leiden: Brill, forthcoming).

7 Already the introductory line to the curriculum is indicative, as it aims to present the "mode of

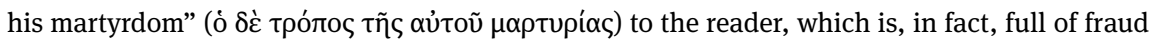
and betrayal: Refutatio omnium haeresium 9,11,4 (GCS 26, 246,13 Wendland).

8 Cf. Handl, Callixtus, der Bischof (see note 6).

9 For the modalities and further details see Handl, Callixtus, der Bischof (see note 6).

10 Refutatio omnium haeresium 9,12,13 (248,10-11 W.; trans. M. David Litwa, Refutation of All Heresies [Writings from the Greco-Roman World 40; Atlanta: SBL Press, 2016], 649, slightly modi-

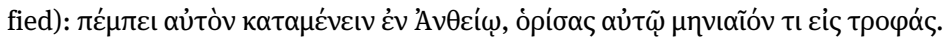

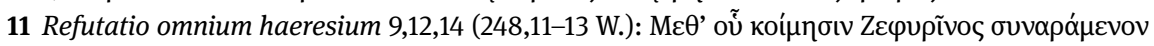

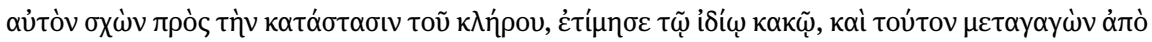

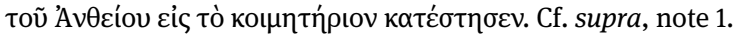


Refutatio likewise records that Callixtus "was always with him," that is, with Zephyrinus, and that the bishop "made him (Callixtus) his partner in everything that he decided."12 One of those "co-orchestrated" decisions was apparently the development of a Christological formula promoting monarchianistic ideas. ${ }^{13}$ If one simply ignores the flood of adjectives with negative connotations implying inter alia greediness, lack of education, or bad influence, ${ }^{14}$ the essence of the passages drafts a realistic picture of Callixtus' tasks and duties as well as of his involvement governing the bishop's church at Rome.

As scholars have already rightly pointed out, the duties described have two common characteristics. The first is the mainly practical orientation of the duties: managing the clergy and the cemetery (Refutatio 9,12,14) and involvement in the policy making process (Refutatio 9,11,3). The second is that Callixtus acted regularly on behalf of bishop Zephyrinus. More concretely, he either acted as a representative of the bishop when he conducted negotiations with heretics (Refutatio $9,11,2-3) ;^{15}$ or carried out some tasks for the bishop, like the management of the cemetery (Refutatio 9,12,14); or advised the bishop, as in the co-development of a Christological formula (Refutatio 9,11,3). What is more, the Refutatio did not assign any liturgical functions to Callixtus. One has to note, however, that the Refutatio shows in general no interest in liturgical matters, unless they involve performing magic, or more precisely, unless they involve dirty tricks which are used for seducing gullible victims. ${ }^{16}$ The weight of the evidence presented here is overwhelming and points clearly in one direction: Callixtus must have assisted

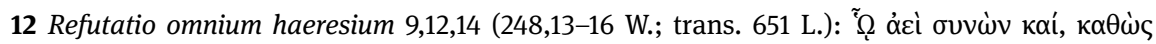

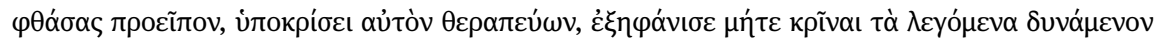

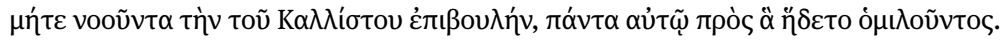

13 Refutatio omnium haeresium 9,11,3 (246,1-4 W.; trans. 645 L.): $\Delta \eta \mu$ oбía ع̋

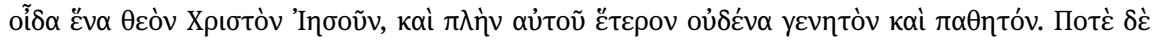

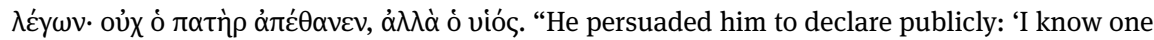
God Christ Jesus, and beside him no other who is born and subject to suffering.' At other times, he persuaded him to say: 'The Father did not die, but the Son.' ” For Callixtus' Christology see Ronald E. Heine, “The Christology of Callistus," JThS 49 (1998): 56-91; Simon Gerber, "Calixt von Rom und der Monarchianische Streit," ZAC 5 (2001): 213-239.

14 E. g. in Refutatio omnium haeresium 9,11,1 or 9,12,14 (245,14-17; 248,11-13 W.).

15 Refutatio omnium haeresium 9,12,2-3 (245,21-246,8 W.).

16 An impressive example is Markos, who, according to the Refutatio, used various tricks to deceive many people. The heresiology elaborated at length two of those tricks, the colourchanging "wine" and the "overflowing wine." Moreover, he also introduced the "ritual of redemption." In those contexts, the Author revealed some details about the Markosian liturgy. Cf. Refutatio omnium haeresium 6,39,2-6,41,3 (170,14-173,2 W.). 
Zephyrinus as a deacon. ${ }^{17}$ This "job description" could indeed hardly be more explicit, unless the text would make use of a proper technical term like $\delta$ iókovos. ${ }^{18}$ In this respect, a further observation caused some irritation to scholars. On the one hand, the Refutatio did mention a monthly allowance paid to Callixtus, but on the other hand, it suppressed both a terminus technicus for his actual ministry and a reference to his ordination. ${ }^{19}$

As far as the ecclesial offices are concerned, the Refutatio systematically ignores them. In the entire work, only two persons are expressis verbis identified as clerical office holders: Irenaeus as presbyter and Victor as bishop. ${ }^{20}$ This obvious reservation does not imply, however, that the Author would in general ignore ecclesial offices or regard them as insignificant. Rather, the Author used to replace his opponents' ecclesial office titles with descriptions, which tend to shed negative light upon the office holder's personal qualities. Callixtus is, for instance, characterised as one "hunting" and finally attaining "the episcopal throne"; ${ }^{21}$ or Zephyrinus is described as a man who "was in charge of the

17 Von Döllinger, Hippolytus und Kallistus (see note 2), 123-124; Giovanni Battista de Rossi, "Esame Archeologico e Critico della Storia di S. Callisto Narrata nel Libro Nono dei Filosofumene," Bullettino di Archeologia Cristiana 4 (1866): (1-14, 17-33, 77-99) 8-10 determined the office as archdeacon. In the past few years, scholars unanimously identified Callixtus' function as that of a deacon: Wolfgang Wischmeyer, Von Golgatha zum Ponte Molle: Studien zur Sozialgeschichte der Kirche im Dritten Jahrhundert (Forschungen zur Kirchen- und Dogmengeschichte 49; Göttingen: Vandenhoeck und Ruprecht, 1992), 101; Éric Rebillard, “Koimetérion et Coemeterium: Tombe, Tombe Sainte, Nécropole,” Mélanges de l'École Française de Rome. Antiquité 105 (1993): 975-1001; Allen Brent, Hippolytus and the Roman Church in the Third Century: Communities in Tension before the Emergence of a Monarch-Bishop (VCS 31; Leiden: Brill, 1995), 295, 437; Prinzivalli, “Callisto I, Santo" (see note 1), 237; Nicola Denzey Lewis, "Reinterpreting 'Pagans' and 'Christians' from Rome's Late Antique Mortuary Evidence,” in Pagans and Christians in Late Antique Rome (ed. Michele Salzman, Marianne Sághy, and Rita Lizzi Testa; Cambridge: Cambridge University Press, 2015), (273-290) 280.

18 In his dissertation, Paul August Leder, Die Diakonen der Bischöfe und Presbyter und ihre Urchristlichen Vorläufer: Untersuchungen über die Vorgeschichte und die Anfänge des Archidiakonats (Kirchenrechtliche Abhandlungen 24; Stuttgart: Enke, 1905), 172-199 expressed his complete lack of understanding towards the sources which simply ignore the "historical fact" that Callixtus was a deacon: "Der Diakonat des Callixtus ist weder in den Philosophumenen (sic!) noch auch anderswo direkt bezeugt; indes er ist eine geschichtliche Tatsache."

19 Domagalski, "Der Diakonat” (see note 3), 19.

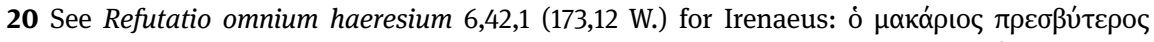

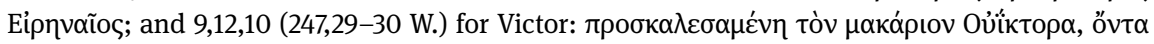

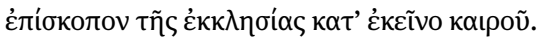

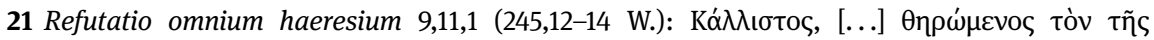

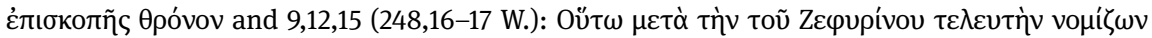

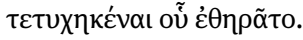


church," 22 yet "unprofessional, illiterate, and inexperienced in ecclesiastical rulings." ${ }^{23}$ This rather creative replacement of clerical offices did not serve-as often suspected-the character assassination of Zephyrinus or of his pupil Callixtus. ${ }^{24}$ Rather, the Author applied here a sophisticated strategy. By omitting or reformulating, he decontextualised both of his episcopal opponents, which helped him downplay or even eliminate the collective legitimation expressed in their ecclesial titles. After all, he was just about to declare two successive bishops of Rome-one of them also an authentic martyr-to be the most dangerous heretics of their times. ${ }^{25}$

Very similar reservations apply to any reference concerning ordinations. An incidental mention of Callixtus' ordination to whichever ministry after his return from the mines would have (in)directly confirmed what most likely happened anyway: that bishop Victor, and with him also Rome's episcopal church, officially recognised Callixtus as an authentic witness to the faith. Such a simple glitch would have been enough to provide a decisive argument against the Author's efforts to discredit Callixtus' martyrdom. Thus, the Author has wisely chosen to remain silent. This is also the main reason why the Author turned the curriculum vitae into a shallow and patchy narrative after Callixtus' return from Sardinia and offered detailed description again, once the ex-slave took personal responsibility for the Roman church as bishop. ${ }^{26}$ Not surprisingly, the Refutatio also keeps silent about Callixtus' ordination to the episcopate after the death of Zephyrinus, as well as about Zephyrinus' ordination after the death of Victor. Therefore, the Refutatio's silence about ordinations cannot be used as an argument either to prove or to disprove the supposed compliance (or divergence) of the Roman practice with that of the Traditio apostolica. ${ }^{27}$

The Refutatio's deliberately incomplete account implies that Callixtus' ministry at the side of bishop Zephyrinus can hardly be decisive for the overall development of his ecclesial career, no matter how overwhelming the evidence might be

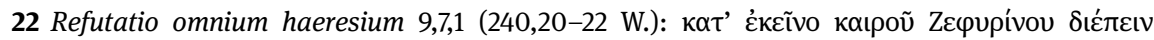

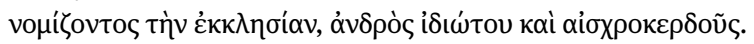

23 Refutatio omnium haeresium 9,11,1 (245,14-15 W.; trans. 643 L., slightly modified): tòv

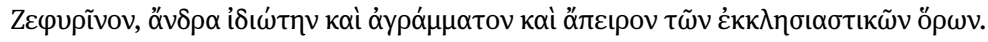

24 Handl, Callixtus, der Bischof (see note 6).

25 In the prooemium to the ninth chapter, where Callixtus and his sect are discussed, the Author lamented that "there still remains the greatest contest: to recount and to refute the heresies that have arisen in my own time.” Refutatio omnium haeresium 9,6 (240,9-11 W.; trans. 621 L.):

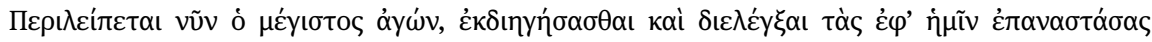

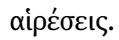

26 Handl, Callixtus, der Bischof (see note 6).

27 Cf. infra, 61-73. 
in this respect. The formative period had to have begun at an earlier point, years before Callixtus' return from the holiday resort of Antium. A marginal yet important remark about the "monthly allowance" seems to be the very first tangible indication of his ecclesial engagement. The note's significance arises, firstly, because it confirms, as I argued elsewhere extensively, ${ }^{28}$ that Victor and thus the episcopal church of Rome recognised Callixtus as an authentic confessor. Secondly, and in this context more importantly, it straightforwardly confirms that Callixtus was put on the payroll of the Roman church. Yet, two at first glance contradictory statements in one sentence complicate the situation: on the one hand, the Author presented the affair as if Callixtus had been exiled to Antium, but on the other hand, the monthly allowance suggests the opposite. Some contemporary accounts might shed some light on this contradiction and explain some basic mechanism at play.

\section{Honour and Ministry}

The first piece of evidence is an anonymous source concerning the heresy of Artemon, transmitted by Eusebios of Caesarea. The church historian recounts a particular incident which took place in Rome, during the tenure of Zephyrinus. One day, the confessor Natalius was approached by Asclepiodotos and Theodotos the Banker, the second generation leaders of the Theodotians, who promoted Adoptionism, a dynamic form of Monarchianism. ${ }^{29}$ "They persuaded Natalius to be called bishop of this heresy, with a salary, so that he received from them one hundred and fifty denarii a month." ${ }^{30}$ Natalius accepted the offer, but after several visions and some torturing by angels he resigned from office and begged Zephyrinus for readmission. ${ }^{31}$ Apparently, the prospect of the most prestigious

28 András Handl, "Bishop Callistus I. of Rome (217?-222). A Martyr or a Confessor?," ZAC 18 (2014): 390-419, particularly 390-403.

29 For the social background of the Theodotians see Peter Lampe, From Paul to Valentinus: Christians at Rome in the First Two Centuries (Minneapolis: Fortress Press, 2003), 344-348, for the doctrines Winrich A. Löhr, "Theodotus der Lederarbeiter und Theodotus der Bankier-ein Beitrag zur Römischen Theologiegeschichte des Zweiten und Dritten Jahrhunderts," ZNW 87 (1996): 101-125.

30 Eusebios, Historia ecclesiastica 5,28,10 (GCS 9,1, 502,21-23 Schwartz; trans. Roy J. Deferrari, Ecclesiastical History: Books 1-5 [FaCh 19; 3rd ed.; Washington: Catholic University of America

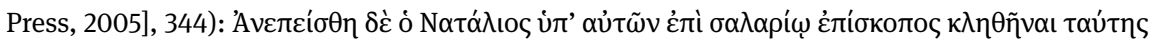

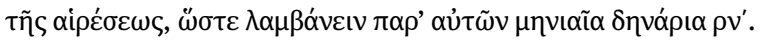

31 Eusebios, Historia ecclesiastica 5,28,11-12 (502,23-504,8 S.). 
ecclesial office, in combination with a solid monthly salary, ${ }^{32}$ was quite seductive. It is needless to say that Natalius was not approached because of his overall qualities, education or the like. Eusebios' anonymous source did not even bother to provide information about Natalius' profession or background. For him, and likewise for the Theodotians, only one factor seemed to be significant: That Natalius was a confessor. And as a confessor, he was considered a chosen one of God, someone who linked earth to heaven and acted with spiritual powers as a privileged intermediary between God and men. ${ }^{33}$ Precisely this intermediary role was appealing to the Theodotians, who merely sought to take advantage of it for their community and hoped to benefit from Natalius's good reputation. An enhancement of their own reputation was indeed badly needed, since bishop Victor had officially broken the community bond with the Thedotians some years before. ${ }^{34}$ It is very unfortunate that Eusebios' source did not provide further insights into Natalius' person. Thus, it must remain obscure whether Natalius did hold an ecclesial office prior to his appointment as bishop of the Theodotians and if so, which one. It is also unclear whether professional services were expected of Natalius as bishop and if so, which ones. Yet, both writers, the anonymous author of the Natalius episode and Eusebios, leave no doubt that Natalius' most important qualification for the episcopal office was the possession of spiritual gifts and the spiritual authority established thereby. In this context, it is particularly interesting to note that neither author polemicises against the appointment of a confessor to paid office, nor against an installation in clerical ministry. The real scandal was in their eyes the fact that "heretics" managed to seduce a confessor, a chosen one of God, who was clothed with and thus guided by the Holy Spirit, and who therefore, by definition, must have been the infallible champion of orthodoxy. ${ }^{35}$

Although it would be problematic to draw direct conclusions about the Callixtus episode from the Natalius incident, its anonymous account nevertheless confirms first-hand that confessors were highly regarded members of the Christian

32 The 150 denarii were certainly not an extravagant sum, but also not minimum wage. It enabled one to live a relatively easy and comfortable life, particularly compared to a day labourer. Lampe, From Paul to Valentinus (see note 29), 346 and cf. Wolfgang Szaivert and Reinhard Wolters, eds., Löhne, Preise, Werte: Quellen zur Römischen Geldwirtschaft (Darmstadt: Wissenschaftliche Buchgesellschaft, 2005), 325-329. In contrast, Schöllgen, Professionalisierung des Klerus (see note 4), 53 estimated it as "bescheidenes Monatsgehalt" (modest monthly salary) compared to the salary of army officers.

33 Bernhard Kötting, "Die Stellung des Konfessors in der Alten Kirche," JbAC 19 (1976): 7-23.

34 Eusebios, Historia ecclesiastica 5,28,9 (502,17-21 S.) and see András Handl, "Viktor I. (189?199?) von Rom und die Entstehung des 'Monarchischen' Episkopats in Rom,” Sacris Erudiri 55 (2016): (7-56) 22-25.

35 Eusebios, Historia ecclesiastica 5,28,11 (502,23-26 S.). 
communities of Rome at the end of the second and beginning of the third century. The affair also documents a certain interrelation between witnessing to the faith, appointment to ecclesial office and the payment of a regular salary. The lack of critique towards this interrelation by the anonymous writer from Rome, or by Eusebios roughly a century later from the East, implies that the practice of promoting confessors in paid ecclesial office as an expression of respect was nothing out of the ordinary. ${ }^{36}$

Another source, the Traditio apostolica, or Apostolic tradition, ${ }^{37}$ a church order in its earliest layer dating back to the beginning of the $3^{\text {rd }}$ century, ${ }^{38}$ pro-

36 Some evidence by Tertullian and Eusebios suggest that confessors were over and over again the successful candidates in episcopal elections. Tertullian, Adversus Valentinianos 4,1 (CChr.SL 2, 755,25-28 Kroymann); Eusebios, Historia ecclesiastica 6,8,7; 6,11,4 (GCS 9,2, 536,24538,2; 542,13-15 Schwartz).

37 For many years, Traditio apostolica was considered as Hippolytos' church order and was believed to have originated in Rome. Eduard Schwartz, Adolf Michaelis, and Theobald Ziegler, Über die Pseudoapostolischen Kirchenordnungen (Schriften der Wissenschaftlichen Gesellschaft in Straßburg 6; Strassburg: Truebner, 1910); Bernard Botte, ed., La Tradition Apostolique d'après les Anciennes Versions (SC 11; Paris: Edition du Cerf, 1946). This position has been defended inter alios by Anders Ekenberg, ed., Hippolytos, Den Apostoliska Traditionen (Kristna Klassiker; Uppsala: Katolska bokförlaget, 1994); Alistair Stewart-Sykes, “Introduction,” in idem, ed., On the Apostolic Tradition (St. Vladimir's Seminary Press "Popular Patristics Series"; Crestwood: St. Vladimir's Seminary Press, 2001), 11-50; Alistair Stewart-Sykes, “'Traditio Apostolica': The Liturgy of Third-Century Rome and the Hippolytean School or quomodo historia liturgica conscribenda sit," St. Vladimir's Theological Quarterly 48 (2004): 233-248. Yet, recent scholarship raised fundamental concerns about its authorship and provenance. Christoph Markschies, "Wer schrieb die sogenannte 'Traditio Apostolica?," in Tauffragen und Bekenntnis: Studien zur sogenannten "Traditio Apostolica", zu den "Interrogationes de fide" und zum "Römischen Glaubensbekenntnis” (ed. Wolfram Kinzig, Christoph Markschies, and Markus Vinzent; AKG 74; Berlin: de Gruyter, 1999), 1-79; Andrea Nicolotti, “Che cos'è la Traditio Apostolica di Ippolito? In Margine ad una Recente Pubblicazione,” Rivista di Storia del Cristianesimo 2 (2005): 219-237; Manlio Simonetti, "Roma Cristiana tra Vescovi e Presbiteri," in Origine delle Catacombe Romane (ed. Vincenzo Fiocchi Nicolai and Jean Guyon; Sussidi allo Studio delle Antichità Cristiane 18; Città del Vaticano: Pontificio Istituto di Archeologia Cristiana, 2006), (29-40) 37-40; Reinhard Meßner, "Die angebliche Traditio Apostolica. Eine neue Textpräsentation," Archiv für Liturgiewissenschaft 58/59 (2016/2017): 1-58, especially 1-6; Paul Bradshaw, "Conclusions Shaping Evidence: An Examination of the Scholarship Surrounding the Supposed Apostolic Tradition of Hippolytus,” in Sanctifying Texts, Transforming Rituals (ed. Paul van Geest, Marcel Poorthuis, and Els Rose; Brill's Studies in Catholic Theology 5; Leiden: Brill, 2017), 13-30.

38 In the past years, a broad consensus has been reached, which defines the work as a piece of "living literature" consisting of several layers from different periods and thus not the product of one single individual. The discussion about the layers' origins is, however, still ongoing and far from a general consensus. Although the section on the confessors likely belongs to the oldest layer, conclusions drawn from the text about the particular situation at Rome must nonetheless 
vides more detailed directions to appointments of confessors in clerical offices. It states that a confessor, "if he was in bonds because of the name of the Lord, shall not have hands laid on him for diaconate or presbyterate, for he has the honor of the presbyterate by his confession." 39 The interpretation of this passage has been subject of some heated debates. Particularly the implied perspective caused some irritation in the past, namely that a lay person can "gain" access to ecclesial office without having hands laid on him, that is, without ordination (by a bishop), but simply by a confession or, as Tertullian already sarcastically noted, by simplex et breve carceris taedium. ${ }^{40}$ While some scholars saw here a proof-text for the phenomenon of honorific ipso facto appointments of confessors into active ministry with or without formal duties, ${ }^{41}$ others disagreed and argued that they received only the honour of the presbyterate, not the active ministry. ${ }^{42}$ In my opinion, the latter interpretation appears to be closer to the intentions of the Tradtion apostolica.

The church order only stipulates that the gifts of the Spirit were considered as equal to the laying on of hands by the bishop during the ordination of a presbyter or a deacon. These gifts are the source of the confessor's spiritual authority for which a public confession before a judge and/or sufferings for the name of the Lord were constitutive elements. In other words, public confession is considered

remain hypothetical. Cf. Nathan Chase, "Another Look at the 'Daily Office' in the Apostolic Tradition," Studia Liturgica 49 (2019): (5-25) 5-9 with further references.

39 Traditio Apostolica 9 (FC 1, 238,1-5 Geerlings; trans. Harold W. Attridge and Paul F. Bradshaw, The Apostolic Tradition [Hermeneia; Minneapolis: Fortress, 2002], 68): Confessor autem, si fuit in vinculis propter nomen domini, non imponetur manus super eum ad diaconatum vel presbyteratum. Habet enim honorem presbyteratus per suam confessionem.

40 Tertullian, Adversus Praxean 1,4 (CChr.SL 2, 1159,20-24 Kroymann/Evans).

41 Kötting, "Stellung des Konfessors" (see note 33), 14-19 provides additional evidence for honorary installations from Alexandria and Carthage. Cf. e. g. Wilhelm Geerlings, "Einleitung zur Traditio Apostolica," in Traditio Apostolica. Apostolische Überlieferung (ed. Wilhelm Geerlings; FC 1; Freiburg: Herder, 1991), (143-208) 171; Schöllgen, Professionalisierung des Klerus (see note 4), 61; Eva Baumkamp, Kommunikation in der Kirche des 3. Jahrhunderts: Bischöfe und Gemeinden zwischen Konflikt und Konsens im Imperium Romanum (STAC 92; Tübingen: Mohr Siebeck, 2014), 134-136.

42 Cf. Bernard Botte, “Le Rituel d’Ordination dans la Tradition Apostolique d'Hippolyte,” Bulletin du Comité des Études 36 (1962): 5-12; Albano Vilela, La Condition Collégiale des Prêtres au IIIe Siècle (Théologie Historique 14; Paris: Beauchesne, 1971), 357-360; Dirk van Damme, "Bekenner und Lehrer. Bemerkungen zu zwei nichtordinierten Kirchenämtern in der Traditio Apostolica," in Divitiae Aegypti: Koptologische und Verwandte Studien zu Ehren von Martin Krause (ed. Cäcilia Fluck; Wiesbaden: Reichert, 1995), 321-330, especially 327; Stewart-Sykes, On the Apostolic Tradition (see note 37), 92-93; Claudia Rapp, Holy Bishops in Late Antiquity: The Nature of Christian Leadership in an Age of Transition (The Transformation of the Classical Heritage 37; Berkeley: University of California Press, 2005), 89-91. 
as a kind of "spiritual ordination" directly administered by the Holy Spirit. This "spiritual ordination" is equal in honour (dignity), and only in honour, to the honour of a presbyter ordained by the bishop by imposition of his hands. An ipso facto appointment to active ministry or a membership in the presbyter's college by virtue of being a confessor is not suggested here. Rather, the opposite seems to be the case. Specifically, the remark that the confessor "shall not have hands laid on him for diaconate or presbyterate" indicates a separate act or distinct appointment to active ministry. It is not the appointment, which is unnecessary, but the imposition of the hands during the installation. Moreover, the explicit mention of "diaconate" in this context would make no sense, if the confessor would have ipso facto been promoted by an honorific appointment into the active ministry of presbyterate. Therefore, all the evidence suggests that the Traditio apostolica made a distinction between the honour (dignity) of an office and actual ministry. Although the church order recognised confessors as possessor of spiritual gifts and defined their honour as equal to the honourable office of the presbyterate, this honour neither implied automatic promotion in active ministry, nor was it equivalent with a promotion in an honorific or honorary office with or without formal duties.

Recently, Paul Bradshaw questioned the legitimacy of both prominent practices in the Traditio apostolica. He argued, that "[n]one, however, questioned whether the statement might never have been the practice anywhere." ${ }^{43}$ It is, however, debatable whether there is indeed no further source that confirms the admission of confessors to clerical ministry without the imposition of hands. ${ }^{44}$ Also, the distinction between honour and actual ministry does not seem to be unique to the Traditio apostolica. During the great persecutions, bishop Cyprian of Carthage (249-258) admitted a good number of confessors to diverse ecclesial ministries, sometimes with the concrete promise of future promotion. ${ }^{45}$ Exactly this happened to the confessors Celerinus and Aurelius. Cyprian installed them in the lower office of reader on the grounds that both were still too young to be admitted to higher clerical ranks. Although the bishop remarks at some point in

43 Bradshaw, "Conclusions Shaping Evidence” (see note 37), 19.

44 Bradshaw, "Conclusions Shaping Evidence" (see note 37), 19 (note 23) had to admit that the definiteness of his claim is limited. Allen Brent, "Cyprian and the Question of ordinatio per confessionem," Studia Patristica 36 (2001): 323-337 made an attempt to demonstrate that the praxis of ordinatio per confessionem forced Cyprian to contest the right of presbyters to reconcile the lapsed.

45 Cyprian, Epistulae 29; 38; 39; 40 (CChr.SL 3b, 137,1-138,23; 183,1-185,46; 186,1-192,97; 193,1195,28 Diercks). For the role of confessors in the Carthaginian church see J. Patout Burns, Cyprian the Bishop (Routledge Early Church Monographs; New York: Routledge, 2002), 19-22. 
his letter that it remains to be seen "whether there is a further step to which he [Celerinus] can be advanced in the church," 46 the overwhelming part of the letter is dominated by a lengthy justification of his decision to appoint Celerinus to be a mere reader. ${ }^{47}$ The letter concludes with the bishop's intention eventually to elevate both Celerinus and Aurelius to the presbyterate. The first step in this direction has been made since Cyprian "already designated the honour of the presbytery for them, that so they may be honoured with the same gift as the presbyters, and may share the monthly divisions in equal quantities." 48 The quoted passages and the letter in general illustrate well some significant aspects of Cyprian's concept of confessorship. The eulogy about the individual achievements of both confessors particularly in combination with a good number of other, more explicit, references leave little doubt about the confessors' spiritual authority. ${ }^{49}$ The justification of his decision to install Celerinus and Aurelius merely as readers implies also that both would deserve a more honourable ministry by virtue of being confessors. Regarding Aurelius, Cyprian articulates this notion expressis verbis: "such a man deserved higher grades of clerical appointment and greater advancement." 50

Their designation for receiving a remuneration (sportulae and divisiones mensuranea) which equals that of presbyters expressed not only a prior lack of appropriate honouring, but also reveals a "horizontal hierarchy" within the individual ecclesiastical ranks because of the different remuneration of both confessors from other readers. ${ }^{51}$ Their designated remuneration also articulates Cyp-

46 Cyprian, Epistula 39,4,2 (CChr.SL 3b, 190,68-69 D.; trans. Graeme W. Clarke, The Letters of St. Cyprian of Carthage [Ancient Christian Writers 44; New York: Newman, 1984], 56): Viderit an sit ulterior gradus ad quem profici in ecclesia possit.

47 Cyprian, Epistula 39,1,1-5,2 (CChr.SL 3b, 186,4-192,97 D.).

48 Cyprian, Epistula 39,5,2 (CChr.SL 3b, 192,91-94 D.; trans. 57 C., slightly modified): Ceterum presbyterii honorem designasse nos illis iam sciatis, ut et sportulis idem cum presbyteris honorentur et divisiones mensurnas aequatis quantitatibus partiantur. See also the commentary to this letter in Clarke, The Letters of St. Cyprian of Carthage (see note 46), 186-194.

49 Cf. e.g. Cyprian, Epistulae 10; 13; 18; 28; 37; 39; 40 (CChr.SL 3b, 46,1-55,118; 71,1-78,110; 100,1-102,129; 133,1-136,55; 177,1-182,90; 186,1-192,97; 193,1-195,28 D.); Epistula 60 (CChr.SL 3c, 374,1-379,98 Diercks).

50 Cyprian, Epistula 38,2,1 (CChr.SL 3b, 184,26-27 D.; trans. 53 C.): Merebatur talis clericae ordinationis ulteriores gradus et incrementa maiora.

51 For the sportula and divisiones mensuranea see Georg Schöllgen, "Sportulae: zur Frühgeschichte des Unterhaltsanspruchs der Kleriker,” ZKG 101 (1990): (1-20) 2-4; Schöllgen, Professionalisierung des Klerus (see note 4), 61-62. Robert Wiśniewski, “The Last Shall Be Last: The Order of Precedence among Clergy in Late Antiquity,” Sacris Erudiri 58 (2019): 321-337, especially 330-332, argues that the remuneration also had a symbolic function, as it demonstrated "horizontal hierarchy" and served along with seniority to display differentiation within the same 
rian's intention to appoint them eventually to an ordained ministry adequate to their spiritual dignity. In this instance, as in the Traditio apostolica, the actual clerical ministry of confessors does not necessarily have to correspond to the honour of their spiritual dignity. What is more, Cyprian's approach makes it clear that it is not the possession of spiritual gifts that qualifies for ordained office, but the local bishop's decision. In this context, very pragmatic considerations played an important role. When he appointed both confessors as readers, he apparently bore in mind his community's and his very own interests on the one hand and the candidates' ability and fitness for the proposed ministry on the other hand. ${ }^{52} \mathrm{His}$ ultimate aim was to ensure, at least on paper, as he put it, that "a confessor can render most profit to his brothers." ${ }^{53}$ All of this suggests that Cyprian considered the honour of confessors and the presbyterate as equal and that he distinguished between the honour of being a confessor and ordained ministry.

Taking the Natalius affair, the witness of the Traditio apostolica and Cyprian's approach into consideration, Callixtus' monthly allowance not only gives the impression that he was recognised by bishop Victor and by the Roman church as an authentic confessor, but also suggests his promotion to clerical ministry. ${ }^{54}$ Although it cannot be determined with certainty whether the episcopal church of Rome defined the dignity of a confessor as equal to the honour of the presbyterate, the unanimous witness of the Traditio apostolica and Cyprian's letters makes such an assumption rather plausible. In contrast, it must remain uncertain whether Callixtus' actual ministry corresponded to a confessor's dignity or not.

clerical rank. Although the material presented by Wiśniewski is from later periods, Cyprian's decision to remunerate the readers Celerinus and Aurelius according the pay scale of presbyters reflects the same mechanisms.

52 For the benefit of the community see e. g. Cyprian, Epistulae 38,2; 39,4 (CChr.SL 3b, 184,28185,46; 190,61-191,79 D.); for the fitness of the candidate e.g. Epistula 38 (CChr.SL 3b, 183,1185,46 D.).

53 Cyprian, Epistula 39,4,2 (CChr.SL 3b, 190,69-72 D.; trans. 56 C., modified): Nihil est in quo magis confessor fratribus prosit quam ut, dum evangelica lectio de ore eius auditur, lectoris fidem quisque audierit imitetur.

54 Similar conclusions reached for instance Schöllgen, Professionalisierung des Klerus (see note 4), 53-55. Brent, "Ordinatio per confessionem" (see note 44), 328, following Kötting, "Stellung des Konfessors” (see note 33), 15 did not consider Victor's monthly allowance as reference for paid ministry. Nonetheless, he reckoned in the lack of reference to ordination or to imposition of hands by Zephyrinus a "good evidence for ordination through confessorship." There are three problems with this statement. Firstly, Brent failed to observe that the "allowance" already refers to remunerated ministry. Secondly, it is based on an argumentum ex silentio. And thirdly, there are other, not necessarily less plausible explanations for the silence of the Refutatio. Cf. supra, 58. 
Specifically, this is because both the Traditio apostolica and Cyprian's approach distinguish clearly between the dignity of a confessor and his actual ministry.

\section{The Other Side of the Coin: Integration, Subordination, Control}

The equating of confessors' and presbyters honour and confessors' association with the clergy as an expression of honour and respect is only one, piously propagated side of the story. The very fact, for instance, that the Traditio apostolica dedicated a separate passage to the confessors suggests already some kind of need for guidelines in dealing with these situations. Or at least, the issue of "how to handle confessors" was important enough to be discussed. ${ }^{55}$ What is more, the pious words about the confessor's honour cleverly conceal the actual intention of the passage, the de facto subordination of confessors to the bishops. In this respect, the church order's intentions are hardly surprising. The period of the second half of the second century and first half of the third century was marked by the struggle for superiority between those with a collective legitimation through their election to clerical ministry and those with a charismatic-spiritual legitimation, namely martyrs and confessors. ${ }^{56}$ Until the beginning of the third century, confessors' authority was still beyond all question, though their uncontested status as the most honourable members of the community, as Hermas took for granted around $150,{ }^{57}$ had begun to fade away. The Natalius incident, Callixtus' decrees, ${ }^{58}$ Tertullian' ${ }^{59}$ and later Cyprian's efforts to combat confessors, the success of the confessor Novatian and his circle of confessors, and the difficulties

55 For the issues of interpreting Traditio apostolica, and particularly the problem of its Sitz im Leben in this context see Bradshaw, "Conclusions Shaping Evidence" (see note 37), 18.

56 Kötting, "Stellung des Konfessors” (see note 33), 16-22; Franz Dünzl, "Bekenner und Märtyrer: Heroen des Volkes-ein Problem für das Amt?,” in Volksglaube im Antiken Christentum: Festschrift Theofried Baumeister (ed. Heike Grieser and Andreas Merkt; Darmstadt: Wissenschaftliche Buchgesellschaft, 2009), (504-524) 511-522. See the contribution of Éric Rebillard, "The Role of Clerics in North African Third-Century Martyr Narratives" in the present issue.

57 Handl, Callixtus, der Bischof (see note 6).

58 Cf. Handl, Callixtus, der Bischof (see note 6).

59 Tertullian, De pudicitia 22,1-5 (CChr.SL 2, 1328,1-1329,28 Dekkers) and see Wiebke Bähnk, Von der Notwendigkeit des Leidens: die Theologie des Martyriums bei Tertullian (Forschungen zur Kirchen- und Dogmengeschichte 78; Göttingen: Vandenhoeck \& Ruprecht, 2001), 268-282; Handl, Callixtus, der Bischof (see note 6). 
of the Roman bishops in mitigating the escalating situation ${ }^{60}$ are merely the most spectacular examples of the struggle for superiority.

One important factor with great potential for conflict was the independent legitimation of confessors. According to widespread opinion, God had directly chosen the confessors, because public confession of faith and the endurance of subsequent sufferings were only possible through the support of the Holy Spirit. ${ }^{61}$ The confessors' authority was, therefore, per definitionem independent of the (local) church and at least on an equal footing if not superior to office holders' collective legitimation. Thus, associating autonomous spiritual authorities with the clergy offered an excellent opportunity to integrate them into the existing local ecclesial structures with their already established systems of hierarchic subordination. ${ }^{62}$ Moreover, an integration facilitated the access of community members to the confessors' spiritual gifts in a supervised and thus controlled setting. In an ideal situation, the integration guaranteed a peaceful co-existence and was beneficial for all the parties involved.

Probably in not a few cases, installation of confessors was also a mean to provide them financial support and thus primarily a work of charity implemented in the form of a professional salary. Some confessors' physical condition was seriously compromised due to torture, longer imprisonment, or forced labour; others might have lost ground economically and socially, particularly members of the lower social classes. ${ }^{63}$

60 A short but illuminating overview about the conflict offers Ronald E. Heine, "Cyprian and Novatian," in The Cambridge History of Early Christian Literature (ed. Frances M. Young; Cambridge: Cambridge University Press, 2004), 152-160. See further Hermann Josef Vogt, Coetus sanctorum: der Kirchenbegriff des Novatian und die Geschichte seiner Sonderkirche (Theophaneia 20; Bonn: Hanstein, 1968); Henneke Gülzow, Cyprian und Novatian: Der Briefwechsel zwischen den Gemeinden in Rom und Karthago zur Zeit der Verfolgung des Kaisers Decius (Beiträge zur Historischen Theologie 48; Tübingen: Mohr Siebeck, 1975); Vera Hirschmann, Die Kirche der Reinen: Kirchen- und Sozialhistorische Studie zu den Novatianern im 3. bis 5. Jahrhundert (STAC 96; Tübingen: Mohr Siebeck, 2015), 75-83.

61 Cyprian, Epistula 38,1,1 (CChr.SL 3b, 183,6-7 D.) gets to the heart of this notion when he with regard to the confessor Aurelius states: "God has cast His vote." Sed expectanda non sunt testimonia humana cum praecedunt divina suffragia. See Kötting, "Stellung des Konfessors" (see note 33), 9 for further references.

62 Van Damme, "Bekenner und Lehrer” (see note 42), 324-326.

63 The one who was condemned to the mines became penal slave (servus penae). Thereby, he lost his social rank, citizenship, liberty, and all property. All of his formal actions including his marriage and testaments were void. Klaus Peter Müller-Eiselt, Divus Pius constituit: Kaiserliches Erbrecht (Freiburger Rechtsgeschichtliche Abhandlungen 5; Berlin: Duncker und Humblot, 1982), 221-231; Fergus Millar, "Condemnation to Hard Labour in the Roman Empire, from the Julio-Claudians to Constantine," Papers of the British School at Rome 52 (1984): 124-147, for con- 
Their integration into the clergy, particularly in combination with a regular remuneration was, however, not only a charitable and pious act, but it also established hierarchic, social, and financial dependency. In hostile situations, the regular remuneration could easily be used as a pressure point to maintain loyalty or force confessors to submit to the elected bishop and follow his lead. Thus, the association of spiritual authorities with clerical ministry could serve as a quite powerful instrument to integrate, subordinate, and in case of (internal) tensions or differences, to ensure their loyalty towards the local Christian community and their collectively legitimated authorities.

Similar mechanisms-asymmetric status, dependency, reciprocity of exchanged goods or services, mutuality, formalised but personal relationship, continuity, etc.--were at play in the well-known patron-client relations of the Roman society. ${ }^{64}$ It has long been observed that due to his aristocratic background, Cyprian's understanding of ecclesial authority and governance style naturally reflected typical patterns of patronage. ${ }^{65}$ Some evidence suggests that such characteristic patterns can also be spotted in the North African ordination rites. As Stewart-Sykes argued convincingly, the spiritual gift of the Holy Spirit, ${ }^{66}$ which is given by the bishop's imposition of hands, can be considered a beneficium and "by virtue of being a gift which in turn empowered would thus bring

demnatio in metallum especially 137-143, and Aglaia McClintock, Servi della Pena: Condannati a Morte nella Roma Imperiale (Pubblicazioni della Facoltà di Economia e del Dipartimento di Studi Giuridici, Politici e Sociali, Sezione Giuridico-Sociale 65; Napoli: Edizioni Scientifiche Italiane, 2010), 11-58.

64 Richard P. Saller, Personal Patronage under the Early Empire (Cambridge: Cambridge University Press, 1982), 1-39; Andrew Wallace-Hadrill, "Patronage in Roman Society: From Republic to Empire," in Patronage in Ancient Society (ed. Andrew Wallace-Hadrill; Leicester Nottingham Studies in Ancient Society 1; London: Routledge, 1989), 63-87.

65 Charles A. Bobertz, Cyprian of Carthage as Patron: A Social Historical Study of the Role of Bishop in the Ancient Christian Community of North Africa (New Haven: Yale University, 1988); Wolfgang Wischmeyer, "Der Bischof im Prozess: Cyprian als episcopus, patronus, advocatus und martyr vor dem Proconsul," in Fructus centesimus: Mélanges Offerts à Gerard J. M. Bartelink à l'Occasion de son Soixante-Cinquième Anniversaire (ed. Antoon A. R. Bastiaensen; Instrumenta Patristica et Mediaevalia 19; Dordrecht: Kluwer, 1989), 363-371; Alistair Stewart-Sykes, "Ordination Rites and Patronage Systems in Third-Century Africa," VigChr 56 (2002): 115-130; Geoffrey Dunn, "Cyprian and His Collegae: Patronage and the Episcopal Synod of 252," Journal of Religious History 27 (2003): 1-13; Allen Brent, Cyprian and Roman Carthage (Cambridge: Cambridge University Press, 2010), 69-75.

66 Cyprian, Epistula 73,9,1 (CChr.SL 3c, 539,147-151 D.): Et idcirco quia legitimum et ecclesiasticum baptisma consecuti fuerant, baptizari eos ultra non oportebat, sed tantummodo quod deerat id a Petro et Iohanne factum est, ut oratione pro eis habita et manu inposita invocaretur et infunderetur super eos spiritus sanctus. 
about an obligation of reciprocation." ${ }^{67}$ In ordination, this beneficium is transmitted by the bishop's laying on of hands constructing a patron-client relationship. In contrast, confessors and martyrs receive their beneficium directly from God by their confession and sufferings, which are constitutive for their spiritual authority. ${ }^{68}$ If both observations are correct, then a network of patronage is created between God as patron and the confessor as client, making the confessor a fully independent actor with no obligations, dependencies, or asymmetries in (spiritual) power towards the church or its ordained ministers. Confessors' admission to paid ministry was therefore a necessary and very efficient way for Cyprian to overcome their independence and to construct a relationship of clientela, similar to his relationship with the members of his clergy he had ordained by the laying on of hands. It is certainly not a coincidence that Cyprian explicitly speaks about sportulae when he describes the allowances which the readers Celerinus and Aurelius should receive according to their honour and which equal that of the presbyters. The word has its origins in the patronage system and its use here implies that a patron-client relationship has successfully been established between the bestower Cyprian and the recipient confessors. ${ }^{69}$ Not only Cyprian's vocabulary reflects typical terms of patronage, but also, and more importantly, all essential characteristics of the modern definition are met. ${ }^{70}$ Confessors offered their spiritual gift and authority in exchange for regular remuneration by the bishop, which corresponds to the reciprocal exchange of goods and services. Moreover, a durable personal relationship was ensured by an appointment to the clergy. And finally, both the status of the parties involved as well as the nature of the goods exchanged were different, since bishops acted as uncontested leaders of Christian communities, while granted the members of the local community access to their spiritual gift for regular remuneration.

Apparently, Cyprian was aware of the potential of patronage networks and was not particularly hesitant to exploit it. Beside Aurelius and Celerinus Cyprian installed at least two other meritorious confessors in clerical ministry while still in exile in order to counter compromised or rebellious clergy in Carthage. ${ }^{71}$ With their support, the bishop managed to regain control over the fragile situation, to restore peace and to extend his influence over such groups as had criticised

67 Stewart-Sykes, “Ordination Rites” (see note 65), 116-126, here 125.

68 Cyprian, Epistula 39,1,1 (CChr.SL 3b, 186,4-9 D.) and cf. Stewart-Sykes, "Ordination Rites” (see note 65), 125.

69 Schöllgen, "Sportulae" (see note 51), 8-9.

70 Cf. Saller, Personal Patronage (see note 64), 1.

71 Cyprian, Epistulae 29,1,2; 38,1; 39,1,1; 40,1,1 (CChr.SL 3b, 138,12-14; 183,1-184,25; 186,9-13; 193,5-10 D.). 
his behaviour when he fled Carthage during persecution. ${ }^{72}$ What is more, he managed to subordinate independent spiritual authorities, securing their loyalty for himself and for his faction in Carthage and thereby channelling very successfully their spiritual authority for his own agenda. Last but not least, he also used their example to send a very clear message to confessors acting contrary to his position in the reconciliation debate by issuing letters of peace for the lapsed which read: "He cannot be a martyr who is not in the Church,"73 that is, not under the bishop's (and thus his own) authority.

Typical mechanisms of patronage can also be observed in the Natalius affair. The salary of 150 denarii was not merely bait to seduce Natalius, but its acceptance established a relationship of patronage and turned him into the dependent of the Theodotians in exchange of his spiritual gift, honour, and respect in Christian communities. From this point on, Natalius was completely out of the range of Zephyrinus' control mechanisms, and the situation became insoluble by man. A divine intervention was required, which eventually put Natalius back on the right track. Although it is not possible to establish a chronological order for these events, the idea is intriguing that Zephyrinus might deliberately have appointed the confessor Callixtus as his personal assistant because of the challenges and setbacks he faced during the Natalius affair. The fact that Zephyrinus was ready to take the risk and call back Callixtus, whose person was, to say the least, controversial among the Christians of Rome, supports this consideration. In any case, Zephyrinus very successfully channelled Callixtus' potential as a confessor for his own purposes.

In light of the evidence, the association of the confessor Callixtus with the clergy by bishop Victor and his remuneration by a monthly allowance implies that he was fully integrated into the episcopal church of Rome. It is possible that his installation in the clergy arose from actual neediness. The ex-slave had just returned from the mines of Sardinia-which was a health hazard in and of itselfwhere he had had to carry out forced labour for a year or even longer. ${ }^{74}$ The monthly allowance probably saved him from further decline. It is also possible that Callixtus' appointment was motivated by considerations widely known from

72 Burns, Cyprian the Bishop (see note 45), 4-8.

73 Cyprian, De ecclesiae catholicae unitate 14 (CChr.SL 3, 259,337-342 Bévenot): Esse martyr non potest qui in ecclesia non est. [...] Exhibere se non potest martyrem qui fraternam non tenuit caritatem.

74 Already Xenophon, Lucretius and later Pliny noted some physiological consequences of working in metal mines. According to Philip Wexler, Toxicology in Antiquity (History of Toxicology and Environmental Health; Amsterdam: Academic Press, 2015), 29, lead poisoning was very common among those who were forced to work in lead mines. 
modern (church) practice. Office holders, who became liabilities because of some misconduct were not discharged, but promoted to a higher or alternative office and thus they were removed from the public gaze. This interpretation is supported by the Refutatio, as the Author explicitly links Callixtus' departure to Antium with the monthly allowance: Victor "sent him to remain in Antium, assigning him a monthly allowance." ${ }^{75}$ Yet, the possibility remains that mentioning the monthly allowance in the first place, for which there is no other plausible explanation, and particularly its subsequent linking to Callixtus' departure to Antium are mainly motivated by the Author's primary aim. Specifically, he reinterpreted every little detail of his arch-enemy's story in order to turn Callixtus' "epic passio" into a story full of slander, betrayal, and fraud. Thus it is hardly surprising that the approach here bears the characteristic signature of the Author's "biographic method." ${ }^{76}$ In any case, the situation had escalated because of Callixtus' manipulations, whether real or imagined, and the confessor was considered increasingly persona non grata in some Christian communities. Victor and the college of presbyters, ${ }^{77}$ to which also the Author of the Refutatio most likely belonged, ${ }^{78}$ had a powerful tool by now at hand, which they apparently used as leverage to motivate Callixtus to vanish into thin air.

\section{Conclusions}

Callixtus' ecclesial career highlights indeed some interesting mechanisms of clerical promotions. The very first tangible reference to the beginning of his ecclesial career is the Refutatio's notice about a "monthly allowance," which Callixtus received from Victor and the Roman church. It implies, first, that Callixtus was recognised as an authentic confessor, and second, that he was installed in a rather vaguely defined ministry, for which he was financially remunerated. This, combined with other verified elements of his biography, ${ }^{79}$ particularly the fact that he was recognised as a confessor on the one hand and that he was a slave before

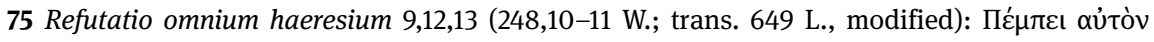

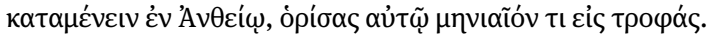

76 Handl, Callixtus, der Bischof (see note 6).

77 For the mechanisms at play which resulted in this decision see Handl, "Viktor I. von Rom" (see note 34), 47-48.

78 Handl, Callixtus, der Bischof (see note 6).

79 Particularly the events before his confession, but also the fact that after his return from Sardinia he acted as a servus sine dominus, point in this direction. Handl, Callixtus, der Bischof (see note 6). 
his condemnation on the other, suggests that Callixtus did not make a clerical career and earn his appointment, but received it by confessing before the praefectus urbi and by his suffering for Christ's name in the lead mines of Sardinia. The early third century Natalius incident confirms that there was a connection between being a confessor and appointment to a paid ecclesial office. From the same period, though of uncertain origins, the Traditio apostolica recognises confessors' honour as equal to that of the presbyterate, but distinguishes between the honour (dignity) of confessors and their actual ministry. Cyprian of Carthage held a similar view as well, when he honoured some confessors by associating them with the lower clergy. His approach reflects characteristic mechanisms of the patron-client relationship and was heavily influenced by the conflict between those who claimed authority based on their courageous stand during persecutions and professional clergy. His letters illustrate that he used appointments to ministry mainly to integrate, to subordinate, and to control confessors, and to exploit their spiritual gifts not only for the benefit of his local church community but also for achieving his own agenda. Similar patterns can also be observed in both the Natalius affair and the Callixtus narrative. The monthly salary of 150 denarii both ensured Natalius' full loyalty towards the Theodotians and removed him from Zephyrinus' sphere of influence, a situation which could only be overcome by divine intervention. Callixtus' appointment to the clergy was in this respect a very successful attempt to integrate an independent hero of faith into the local hierarchy and community. The monthly allowance paid to him honoured his spiritual achievement, secured his otherwise rather precarious existence, and last but not least, also offered a pressure point. Without batting an eyelid, bishop Victor and the college of presbyters exploited this pressure point to motivate him to leave for Antium once the situation in Rome became too hot to handle.

It cannot be determined with certainty whether the dignity of the confessor Callixtus was considered to be equal to the honour of the presbyterate in Rome also, or whether his appointed ministry corresponded to this dignity. Nevertheless, some sporadic evidence implies that his dignity and possibly his ministry might have been presbyterial in nature. Both sources, the Traditio apostolica and Cyprian converge in these respects. Both suggest that the dignity of confessors is equal to the honour of the presbyterate, which leaves little space for alternative suggestions. Likewise, both witnesses differentiate between the dignity and the actual ministry, which implies that a linking of dignity to ministry did not ipso facto take place. Rather, it depended on the decision of the local bishop. However, both Cyprian's explanations for installing the confessors Celerinus and Aurelius as readers and the bishop's struggle to prevent the pardoning of the lapsed Christians by confessors without episcopal authorisation, imply that the divinespiritual agency of confessors had its natural place in a liturgical and disciplinary 
context. This might also have been so in the case of Callixtus and would explain his sensitivity for disciplinary issues during his tenure as bishop. ${ }^{80}$

Ultimately, the precise determination of Callixtus' clerical ministry plays a marginal role, if any, in his formation and further ecclesial career. His confession in front of the praefectus urbi as well as his sentence to the mines were decisive. All further developments have their origins here.

Acknowledgements: Parts of this research have received funding from the European Union's Horizon 2020 research and innovation programme under the Marie Skłodowska-Curie grant agreement No 665501 in form of a FWO [PEGASUS] ${ }^{2}$ Marie Skłodowska-Curie fellowships Nr. 12T3717N to the author. I would also like to express my gratitude to Robert Wiśniewski for his insightful comments on an earlier version of this essay.

80 Cf. Handl, Callixtus, der Bischof (see note 6). Cahal Brendan Daly, "The 'Edict of Callistus,'” Studia Patristica 3 (1961): 176-182 offers a good overview for the earlier research. 